\title{
Analysis of the color alteration and radiopacity promoted by bismuth oxide in calcium silicate cement
}

\begin{abstract}
Marina Angélica Marciano(a) Carlos Estrela ${ }^{(b)}$

Rafael Francisco Lia Mondelli(a) Ronald Ordinola-Zapata(a) Marco Antonio Hungaro Duarte ${ }^{(a)}$
\end{abstract}

(a) Department of Operative Dentistry, Endodontics and Dental Materials, Bauru School of Dentistry, Universidade de São Paulo - USP, Bauru, SP, Brazil.

(b) Department of Prevention and Oral Rehabilitation, School of Dentistry, Universidade de Goiás - UFG, Goiânia, GO, Brazil.
Declaration of Interests: The authors certify that they have no commercial or associative interest that represents a conflict of interest in connection with the manuscript.

Corresponding Author:

Marina Angélica Marciano

E-mail: marinangelica@usp.br

Submitted: Feb 06, 2013

Accepted for publication: Apr 08, 2013

Last revision: Apr 29, 2013
Abstract: The aim of the study was to determine if the increase in radiopacity provided by bismuth oxide is related to the color alteration of calcium silicate-based cement. Calcium silicate cement (CSC) was mixed with $0 \%, 15 \%, 20 \%, 30 \%$ and $50 \%$ of bismuth oxide (BO), determined by weight. Mineral trioxide aggregate (MTA) was the control group. The radiopacity test was performed according to ISO 6876/2001. The color was evaluated using the CIE system. The assessments were performed after 24 hours, 7 and 30 days of setting time, using a spectrophotometer to obtain the $\Delta \mathrm{E}, \Delta \mathrm{a}, \Delta \mathrm{b}$ and $\Delta \mathrm{L}$ values. The statistical analyses were performed using the Kruskal-Wallis/Dunn and ANOVA/ Tukey tests $(\mathrm{p}<0.05)$. The cements in which bismuth oxide was added showed radiopacity corresponding to the ISO recommendations ( $>3 \mathrm{~mm}$ equivalent of Al). The MTA group was statistically similar to the $\mathrm{CSC} / 30 \% \mathrm{BO}$ group $(\mathrm{p}>0.05)$. In regard to color, the increase of bismuth oxide resulted in a decrease in the $\Delta \mathrm{E}$ value of the calcium silicate cement. The CSC group presented statistically higher $\triangle \mathrm{E}$ values than the CSC/50\% BO group ( $\mathrm{p}<0.05)$. The comparison between 24 hours and 7 days showed higher $\triangle \mathrm{E}$ for the MTA group, with statistical differences for the CSC/ $15 \% \mathrm{BO}$ and CSC/50\% BO groups ( $\mathrm{p}<0.05)$. After 30 days, CSC showed statistically higher $\Delta \mathrm{E}$ values than $\mathrm{CSC} / 30 \% \mathrm{BO}$ and $\mathrm{CSC} / 50 \% \mathrm{BO}(\mathrm{p}<0.05)$. In conclusion, the increase in radiopacity provided by bismuth oxide has no relation to the color alteration of calcium silicate-based cements.

Descriptors: Endodontics; Bismuth; Color.

\section{Introduction}

Mineral trioxide aggregate (MTA) has been used for several procedures including vital pulp therapies, ${ }^{1}$ root fractures, ${ }^{2}$ perforations ${ }^{3}$ and apexifications, ${ }^{4}$ with a high rate of success. It is well known that calcium silicate is the main component of MTA. ${ }^{5}$ Previous studies have shown that calcium silicate and MTA present similar chemical, physical and biological properties, ${ }^{6-8}$ with the exception of radiopacity. ${ }^{8-10}$ Calcium silicate does not have the minimum radiopacity recommended $(3 \mathrm{~mm}$ equivalent of Al) by ISO 6876/2001 specifications. ${ }^{11}$ Thus, a radiopacifier agent should be added in order to distinguish it from anatomical structures, in clinical conditions. ${ }^{9}$ Several radiopacity agents have been proposed for calcium silicate cement composition such as zirconium oxide, 
calcium tungstate, iodoform and bismuth oxide., ${ }^{9,12}$

Bismuth oxide $\left(\mathrm{Bi}_{2} \mathrm{O}_{3}\right)$ is a yellow substance commonly added to various endodontic materials, e.g., MTA, AH 26 and Sealer 26, for the purpose of providing radiopacity. ${ }^{13-15}$ The use of MTA as a pulp capping material in esthetic areas requires taking into account the changes in color of the dentin. Teeth discoloration is an undesirable consequence of some materials used in endodontic therapy. ${ }^{16-18}$ Color alteration of calcium silicate-based cements has been reported. ${ }^{17,19-21}$ It has been suggested that the radiopacifier bismuth oxide, present in the MTA composition, is the main cause of dental discoloration. ${ }^{22}$ Furthermore, it has been previously demonstrated that AH 26 sealer, which also contains bismuth oxide, results in tooth discoloration. ${ }^{18}$ Thus, it is possible that the presence of bismuth oxide in calcium silicate-based cements and in AH 26 sealer may induce discoloration over time. This hypothesis has been discussed in the literature, but there is no quantitative evidence in this regard. ${ }^{16}$ The aim of the present study was to investigate if there is a relation between the increase in radiopacity provided by bismuth oxide and the color alteration of calcium silicate-based cement. The hypotheses tested were that the increase in the amount of bismuth oxide in the calcium silicate cement increases the radiopacity of this cement and interferes with the color of the material.

\section{Methodology}

A portion of calcium silicate cement (CSC; Irajazinho Votorantim, Cimento Rio Branco, Rio de Janeiro, Brazil) was mixed with 0\%, 15\%, 20\%, 30\% and $50 \%$ of bismuth oxide (BO; Merck, New Jersey, USA), proportioned in weight using an electronic analytic scale (Mettler Toledo PG5002-S, São Paulo, Brazil). MTA was used as the control group. The cements were divided into 6 groups:

- Group 1: MTA,

- Group 2: $100 \mathrm{~g}$ of CSC and $0 \mathrm{~g}$ of BO,

- Group 3: 85g of CSC and 15g of BO,

- Group 4: 80g of CSC and 20g of BO,

- Group 5: 70g of CSC and 30g of BO and

- Group 6: 50g of CSC and 50g of BO.

The manipulation of the cements was performed using a total of $1 \mathrm{~g}$ of cement and $0.4 \mathrm{~mL}$ of distilled water.

\section{Radiopacity}

Three cylindrical samples were fabricated for each concentration by placing the manipulated cements into metallic rings with a $10 \mathrm{~mm}$ internal diameter and a $1 \mathrm{~mm}$ thickness (ISO 6876/2001). ${ }^{11}$ Next, the filled rings were kept at $37^{\circ} \mathrm{C}$, until the cements set completely. The thickness was confirmed with a digital caliper (Mitutoyo Corp., Tokyo, Japan) and the samples were radiographed on occlusal films (D-speed; Kodak Comp., New York, USA) with an aluminum step-wedge, graduated from 2 to $16 \mathrm{~mm}$ (in 2-mm increments). A radiographic unit (Gnatus XR 6010; Gnatus, São Paulo, Brazil) was used with the exposures set at $60 \mathrm{kV}, 10 \mathrm{~mA}, 0.3$ seconds and a focus-film distance of $30 \mathrm{~cm}$. The radiographs were digitized and analyzed using the Digora 1.51 software (Soredex, Helsinki, Finland). The radiopacity was determined according to Duarte et al. ${ }^{9}$

\section{Color assessment}

Ten cylindrical stainless steel rings with an inner diameter of $10 \mathrm{~mm}$ and thickness of $2 \mathrm{~mm}$ were filled with the cements. They were stored in an incubator at $37^{\circ} \mathrm{C}, 100 \%$ humidity, for 24 hours to set completely. After the completion of the setting time, the cements were demolded and the baseline color of the specimens was measured with a spectrophotometer (Vita Easyshade, Vita Zahnfabrik H. Rauter, Bad Säckingen, Germany) against a white Teflon background to obtain the values of lightness ( $\left.\mathrm{L}^{*}\right)$, red-green axis $\left(a^{*}\right)$ and yellow-blue axis $\left(b^{*}\right)$. Three measurements were performed for each sample. The samples were then stored at $37^{\circ} \mathrm{C}, 100 \%$ humidity, for 30 days, and the measurements were repeated. The color changes $(\Delta \mathrm{E})$ were calculated based on the $\Delta L^{*}\left(L_{2}-L_{1}\right), \Delta a^{*}$ $\left(a_{2}-a_{1}\right)$ and $\Delta b^{*}\left(b_{2}-b_{1}\right)$ values for each specimen, according to the following equation: ${ }^{23}$

$$
\Delta E=\left[\left(L_{2}-L_{1}\right)^{2}+\left(a_{2}-a_{1}\right)^{2}+\left(b_{2}-b_{1}\right)^{2}\right]^{1 / 2}
$$

In which $\mathrm{L}_{1}, \mathrm{a}_{1}$ and $\mathrm{b}_{1}$ are the initial assessment color values and $L_{2}, a_{2}$ and $b_{2}$ are the final assessment color values. 
Table 1 - Mean and standard deviation of $\Delta \mathrm{E}, \Delta \mathrm{a}, \Delta \mathrm{b}$ and $\Delta \mathrm{L}$ in initial 24 hours and after 7 days.

Lowercase letters in columns

indicate statistically significant difference among the groups $(p<0.05)$.

\begin{tabular}{c|c|c|c|c}
\hline Group & $\Delta \mathrm{E}$ & $\Delta \mathrm{a}$ & $\Delta \mathrm{b}$ & $\Delta \mathrm{L}$ \\
\hline MTA & $16.96 \pm 14.29^{\mathrm{a}}$ & $1.03 \pm 1.01^{\mathrm{a}}$ & $3.99 \pm 1.83^{\mathrm{a}}$ & $3.01 \pm 2.08^{\mathrm{a}}$ \\
\hline $\mathrm{CSC}$ & $13.00 \pm 5.31^{\mathrm{a}}$ & $1.36 \pm 0.39^{\mathrm{a}}$ & $2.63 \pm 0.99^{\mathrm{b}}$ & $2.94 \pm 2.90^{\mathrm{a}}$ \\
\hline $\mathrm{CSC} / 15 \% \mathrm{BO}$ & $5.67 \pm 5.69^{\mathrm{bc}}$ & $1.82 \pm 0.69^{\mathrm{ab}}$ & $0.26 \pm 0.94^{\mathrm{c}}$ & $2.13 \pm 1.56^{\mathrm{ab}}$ \\
\hline $\mathrm{CSC} / 20 \% \mathrm{BO}$ & $8.51 \pm 8.49^{\mathrm{ac}}$ & $1.70 \pm 0.80^{\mathrm{ab}}$ & $-1.66 \pm 0.31^{\mathrm{d}}$ & $0.22 \pm 3.44^{\mathrm{abc}}$ \\
\hline $\mathrm{CSC} / 30 \% \mathrm{BO}$ & $7.25 \pm 3.50^{\mathrm{ac}}$ & $2.32 \pm 0.21^{\mathrm{b}}$ & $-1.77 \pm 0.64^{\mathrm{d}}$ & $-1.42 \pm 1.99^{\mathrm{bc}}$ \\
\hline $\mathrm{CSC} / 50 \% \mathrm{BO}$ & $4.18 \pm 1.71^{\mathrm{bc}}$ & $1.87 \pm 0.14^{\mathrm{ab}}$ & $-1.48 \pm 0.28^{\mathrm{d}}$ & $-1.52 \pm 0.55^{\mathrm{c}}$ \\
\hline
\end{tabular}

Table 2 - Mean and standard deviation of $\Delta \mathrm{E}, \Delta \mathrm{a}, \Delta \mathrm{b}$ and $\Delta \mathrm{L}$ in initial 24 hours and after 30 days. Lowercase letters in columns indicate statistically significant difference among the groups $(p<0.05)$.

\begin{tabular}{c|c|c|c|c}
\hline Group & $\Delta \mathrm{E}$ & $\Delta \mathrm{a}$ & $\Delta \mathrm{b}$ & $\Delta \mathrm{L}$ \\
\hline MTA & $54.65 \pm 33.26^{\mathrm{a}}$ & $3.93 \pm 1.46^{\mathrm{a}}$ & $7.06 \pm 2.69^{\mathrm{a}}$ & $4.84 \pm 3.66^{\mathrm{ab}}$ \\
\hline $\mathrm{CSC}$ & $66.87 \pm 15.80^{\mathrm{a}}$ & $3.56 \pm 0.51^{\mathrm{a}}$ & $7.39 \pm 0.81^{\mathrm{a}}$ & $7.71 \pm 2.61^{\mathrm{b}}$ \\
\hline $\mathrm{CSC} / 15 \% \mathrm{BO}$ & $41.50 \pm 18.54^{\mathrm{ab}}$ & $3.59 \pm 0.67^{\mathrm{acd}}$ & $4.98 \pm 1.05^{\mathrm{ab}}$ & $6.38 \pm 1.88^{\mathrm{ab}}$ \\
\hline $\mathrm{CSC} / 20 \% \mathrm{BO}$ & $24.30 \pm 8.18^{\mathrm{abc}}$ & $3.20 \pm 0.88^{\mathrm{acd}}$ & $2.68 \pm 0.34^{\mathrm{bc}}$ & $4.38 \pm 3.52^{\mathrm{ab}}$ \\
\hline $\mathrm{CSC} / 30 \% \mathrm{BO}$ & $13.98 \pm 6.64^{\mathrm{bc}}$ & $3.46 \pm 0.25^{\mathrm{ac}}$ & $2.13 \pm 0.66^{\mathrm{bc}}$ & $2.71 \pm 2.01^{\circ}$ \\
\hline $\mathrm{CSC} / 50 \% \mathrm{BO}$ & $8.73 \pm 0.63^{\mathrm{c}}$ & $2.75 \pm 0.27^{\mathrm{bd}}$ & $1.79 \pm 0.11^{\mathrm{c}}$ & $2.53 \pm 0.50^{\mathrm{a}}$ \\
\hline
\end{tabular}

The values of $\mathrm{L}^{*}$ represent the value (lightness or darkness); $a^{*}$ is a measure of redness (positive $a^{*}$ ) or greenness (negative $\left.\mathrm{a}^{*}\right) ; \mathrm{b}^{*}$ is a measure of yellowness (positive $b^{*}$ ) or blueness (negative $b^{*}$ ); and $\Delta \mathrm{E}$ represents the color change. A color difference of $\Delta \mathrm{E}<4.0$ has been shown to represent clinically acceptable color matching. ${ }^{24}$

\section{Statistical analysis}

Statistical analysis was performed using the nonparametric Kruskal-Wallis and Dunn tests for color and radiopacity $(\mathrm{p}<0.05)$. Insofar as the values for $\Delta \mathrm{b}$ showed normality after 7 days, the ANOVA/ Tukey test was used $(\mathrm{p}<0.05)$.

\section{Results}

The values for radiopacity and the statistical differences are represented in Figure 1. All experimental groups in which $\mathrm{BO}$ was added presented radiopacity values higher than a $3 \mathrm{~mm}$ equivalent of Al. MTA was significantly more radiopaque than CSC, $\mathrm{CSC} / 15 \% \mathrm{BO}$ and CSC/20\% BO (p < 0.05). MTA was statistically similar to CSC/30\% BO ( $p>0.05$ ). The CSC/50\% BO group was significantly more radiopaque than all the other groups evaluated $(\mathrm{p}<0.05)$. The statistical differences in color of the cements after 7 and 30 days are shown in Table 1 and 2, respec-

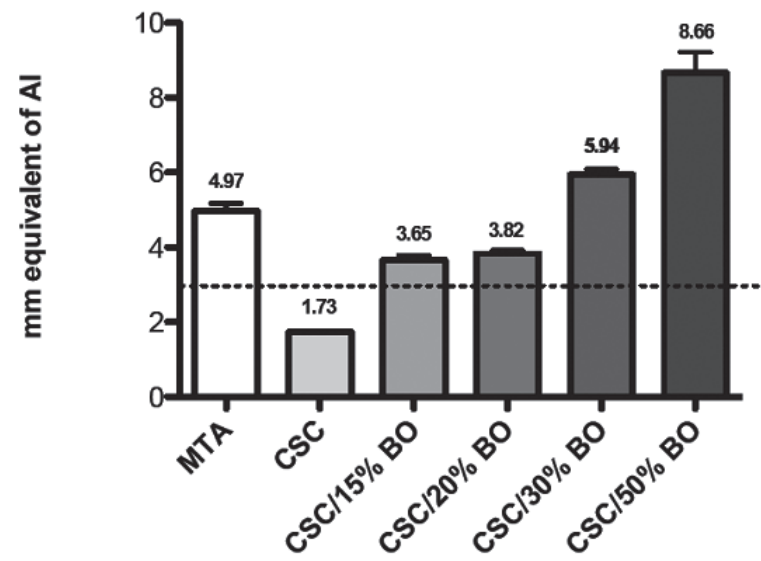

Figure 1 - Mean and standard deviation of radiopacity valves in millimeters of aluminum equivalent.

tively. The higher $\Delta \mathrm{E}$ values were found for MTA at 7 days and for CSC after 30 days. All cements showed $\Delta \mathrm{E}$ values higher than 4.0. Regarding the $\Delta \mathrm{a}$ values, all cements showed positive values at 7 and 30 days, indicating a tendency toward the redness axis. The evaluation of $\Delta \mathrm{b}$ values at 7 days showed positive values for MTA, CSC and CSC/15\% BO, indicating yellowness, whereas the other cements showed negative values, indicating blueness. The analysis of color after 7 days showed higher values of $\Delta \mathrm{L}$ for MTA and lower values for $\mathrm{CSC} / 50 \% \mathrm{BO}$. 


\section{Discussion}

The hypotheses tested in the present study were that an increase in the amount of bismuth oxide in calcium silicate-based cement could increase radiopacity, and additionally interfere with the color of the cement. In regard to radiopacity, the hypothesis was accepted. Higher amounts of bismuth have significantly increased the radiopacity of the cement. Radiopacity is an important physical property required for cements..$^{25} \mathrm{~A}$ minimal value of radiopacity is essential to identify the material in the root canal, and allow filling failures to be corrected prior to final restoration. ${ }^{9}$ The analysis of the results showed that at least $15 \%$ of bismuth oxide must be added to provide the minimum radiopacity required by ISO $6876 / 2001$ specifications ( $3 \mathrm{~mm}$ equivalent of $\mathrm{Al}$ ). ${ }^{11}$ Similar results were previously reported by Bueno et al. ${ }^{26}$ The results reinforce the need to add a radiopacifier agent to calcium silicate-based cement. ${ }^{9}$ The addition of $30 \%$ of $\mathrm{BO}$ to CSC provided a radiopacity statistically similar to that presented by MTA Angelus ( $\mathrm{p}>0.05)$. A previous analysis of MTA Angelus showed that the proportion of $20 \%$ of bismuth oxide provided a radiopacity corresponding to $5.93 \mathrm{~mm}$ equivalent of $\mathrm{Al} .^{9}$ This difference in the results may be associated with the difficulty to obtain homogeneity of CSC and bismuth powders. It is possible that a portion of the cement contained higher or lower amounts of bismuth, and thus influenced the results.

The use of calcium silicate-based cements in vital pulp therapy causes concern regarding the color alteration of the cement and consequent dentin discoloration. The methods used to evaluate the color of materials include subjective ${ }^{27}$ and quantitative analyses. ${ }^{28}$ It has already been shown that sphere spectrophotometers, such as that used in this study, provide a more accurate assessment of the color change than subjective human evaluation. ${ }^{29}$ This equipment measures the amount of visible radiant energy reflected or transmitted by an object, one wavelength at a time for each value, chroma, and hue present in the entire visible spectrum.

The change between the initial and the final color $(\Delta \mathrm{E})$ specify the color alteration of the material during a determined period of time. Previous laboratory and clinical studies have reported dental discoloration after using MTA. ${ }^{17,19,21}$ Therefore, it is necessary to study if the agent responsible for the color alteration without the interference of other factors such as blood, dentin or saliva is actually the cement or its metallic components (bismuth). The $\Delta \mathrm{E}$ observed for all the tested materials was higher than 3.3, which is not considered clinically acceptable. ${ }^{24}$ Thus, the hypothesis tested was denied. Controversially, the increase of $\mathrm{BO}$ decreased the $\Delta \mathrm{E}$ of the calcium silicate cement. The CSC group presented statistically higher $\Delta \mathrm{E}$ values than the CSC $/ 50 \% \mathrm{BO}(\mathrm{p}<0.05)$. These results could suggest that the main cause of discoloration of the cement was the calcium silicate and not the bismuth oxide. However, it is not possible to state that this change in color is clinically reproduced by the absence of components, such as dentin. It is possible that substances present in the dentin react with the components of CSC, including the bismuth oxide, to induce a chemical reaction of reduction resulting in darkness. Other factors may also be correlated with MTA darkness, such as the light curing performed when some restorative materials are used. Vallés et al. ${ }^{30}$ suggest that an association between oxygen supply and light curing alter the color of MTA cement.

The radiopacifier bismuth oxide is yellow in color; however, contrary to what would be expected, the addition of a high proportion of bismuth oxide to calcium silicate cement did not result in an increase in yellowness $(\Delta \mathrm{b})$. At 7 days of analysis, CSC with $20 \%, 30 \%$ and $50 \%$ of $\mathrm{BO}$ showed a tendency toward blueness (negative values), whereas CSC, $\mathrm{CSC} / 15 \% \mathrm{BO}$ and MTA presented a tendency toward yellowness. After 30 days, all cements showed positive values of $\Delta b$, indicating a tendency to produce a yellow color. The findings indicated an inverse correlation between increase of bismuth oxide and color change in calcium silicate-based cements. However, further evaluations are required to clarify the chemical reactions involved in the color changes of these cements.

\section{Conclusion}

It may be concluded that the increase in radi- 
opacity provided by bismuth oxide has no relation to the color change in calcium silicate-based cements. Other factors that may be associated with the reaction could cause the result in color change of calcium silicate-based cements.

\section{References}

1. Eskandarizadeh A, Shahpasandzadeh MH, Shahpasandzadeh M, Torabi M, Parirokh M. A comparative study on dental pulp response to calcium hydroxide, white and grey mineral trioxide aggregate as pulp capping agents. J Conserv Dent. 2011 Oct;14(4):351-5.

2. Roig M, Espona J, Mercade M, Duran-Sindreu F. Horizontal root fracture treated with MTA, a case report with a 10-year follow-up. Dent Traumatol. 2011 Dec;27(6):460-3.

3. Mente J, Hage N, Pfefferle T, Koch MJ, Geletneky B, Dreyhaupt J, et al. Treatment outcome of mineral trioxide aggregate: repair of root perforations. J Endod. 2010 Feb;36(2):20813.

4. Damle SG, Bhattal H, Loomba A. Apexification of anterior teeth: a comparative evaluation of mineral trioxide aggregate and calcium hydroxide paste. J Clin Pediatr Dent. 2012 Spring;36(3):263-8.

5. Song JS, Mante FK, Romanow WJ, Kim S. Chemical analysis of powder and set forms of Portland cement, gray ProRoot MTA, white ProRoot MTA, and gray MTA-Angelus. Oral Surg Oral Med Oral Pathol Oral Radiol Endod. 2006 Dec;102(6):809-15.

6. Estrela C, Sydney GB, Bammann LL, Felippe Junior O. Mechanism of action of calcium and hydroxyl ions of calcium hydroxide on tissue and bacteria. Braz Dent J. 1995;6(2):85-90.

7. Holland R, Souza V, Murata SS, Nery MJ, Bernabe PF, Otoboni Filho JA, Dezan Júnior E. Healing process of dog dental pulp after pulpotomy and pulp covering with mineral trioxide aggregate or Portland cement. Braz Dent J. 2001;12(2):109-13.

8. Saidon J, He J, Zhu Q, Safavi K, Spangberg LS. Cell and tissue reactions to mineral trioxide aggregate and Portland cement. Oral Surg Oral Med Oral Pathol Oral Radiol Endod. 2003 Apr;95(4):483-9.

9. Duarte MAH, El Kadre GDO, Vivan RR, Tanomaru JMG, Tanomaru Filho M, Moraes IG. Radiopacity of portland cement associated with different radiopacifying agents. J Endod. 2009 May;35(5):737-40.

10. Islam I, Chng HK, Yap AU. Comparison of the physical and mechanical properties of MTA and portland cement. J Endod. 2006 Mar;32(3):193-7.

11. International Organization for Standardization. ISO 6876: Dental Root Canal Sealing Materials. Geneva: International Organization for Standardization; 2001. 18 p.

\section{Acknowledgments}

This work was supported by the Coordenação de Aperfeiçoamento de Pessoal de Nível Superior (CAPES) and Fundação de Amparo à Pesquisa do Estado de São Paulo (FAPESP), process \#2011/13573-3.

12. Camilleri J, Cutajar A, Mallia B. Hydration characteristics of zirconium oxide replaced Portland cement for use as a rootend filling material. Dent Mat. 2011 Aug;27(8):845-54.

13. Ersev H, Schmalz G, Bayirli G, Schweikl H. Cytotoxic and mutagenic potencies of various root canal filling materials in eukaryotic and prokaryotic cells in vitro. J Endod. 1999 May;25(5):359-63.

14. Tanomaru-Filho M, Faleiros FBC, Sacaki JN, Duarte MAH, Tanomaru JMG. Evaluation of $\mathrm{pH}$ and calcium ion release of root-end filling materials containing calcium hydroxide or mineral trioxide aggregate. J Endod. 2009 Oct;35(10):141821.

15. Torabinejad M, Hong CU, McDonald F, Pitt Ford TR. Physical and chemical properties of a new root-end filling material. J Endod. 1995 Jul;21(7):349-53.

16. Krastl G, Allgayer N, Lenherr P, Filippi A, Taneja P, Weiger $\mathrm{R}$. Tooth discoloration induced by endodontic materials: a literature review. Dent Traumatol. 2013 Feb;29(1):2-7

17. Lenherr P, Allgayer N, Weiger R, Filippi A, Attin T, Krastl G. Tooth discoloration induced by endodontic materials: a laboratory study. Int Endod J. 2012 Oct;45(10):942-9.

18. van der Burgt TP, Mullaney TP, Plasschaert AJ. Tooth discoloration induced by endodontic sealers. Oral Surg Oral Med Oral Pathol. 1986 Jan;61(1):84-9.

19. Belobrov I, Parashos P. Treatment of tooth discoloration after the use of white mineral trioxide aggregate. J Endod. 2011 Jul;37(7):1017-20.

20. Bortoluzzi EA, Araujo GS, Tanomaru JMG, Tanomaru-Filho M. Marginal gingiva discoloration by gray MTA: a case report. J Endod. 2007 Mar;33(3):325-7.

21. Karabucak B, Li D, Lim J, Iqbal M. Vital pulp therapy with mineral trioxide aggregate. Dent Traumatol. 2005 Aug;21(4):240-3.

22. Steffen R, van Waes H. Understanding mineral trioxide aggregate/portland-cement: a review of literature and background factors. Eur Arch Paediatr Dent. 2009 Jun;10(2):93-7.

23. Lenherr P, Allgayer N, Weiger R, Filippi A, Attin T, Krastl G. Tooth discoloration induced by endodontic materials: a laboratory study. Int Endod J. 2012 Oct;45(10):942-9.

24. Ruyter IE, Nilner K, Moller B. Color stability of dental composite resin materials for crown and bridge veneers. Dent Mater. 1987 Oct;3(5):246-51. 
25. Tanomaru JMG, Duarte MAH, Gonçalves M, TanomaruFilho M. Radiopacity evaluation of root canal sealers containing calcium hydroxide and MTA. Braz Oral Res. 2009 Apr-Jun;23(2):119-23.

26. Bueno CE, Zeferino EG, Manhaes Jr LRC, Rocha DG, Cunha RS, De Martin AS. Study of the bismuth oxide concentration required to provide Portland cement with adequate radiopacity for endodontic use. Oral Surg Oral Med Oral Pathol Oral Radiol Endod. 2009 Jan;107(1):e65-9.

27. Rotstein I, Mor C, Friedman S. Prognosis of intracoronal bleaching with sodium perborate preparation in vitro: 1-year study. J Endod. 1993 Jan;19(1):10-2.
28. Martin-Biedma B, Gonzalez-Gonzalez T, Lopes M, Lopes L, Vilar R, Bahillo J, Varela-Patiño P. Colorimeter and scanning electron microscopy analysis of teeth submitted to internal bleaching. J Endod. 2010 Feb;36(2):334-7.

29. Horn DJ, Bulan-Brady J, Hicks ML. Sphere spectrophotometer versus human evaluation of tooth shade. J Endod. 1998 Dec;24(12):786-90.

30. Vallés M, Mercadé M, Duran-Sindreu F, Bourdelande JL, Roig M. Influence of light and oxygen on the color stability of five calcium silicate-based materials. J Endod. 2013 Apr;39(4):525-8. 